\title{
Low Mitosis-Karyorrhexis Index
}

National Cancer Institute

\section{Source}

National Cancer Institute. Low Mitosis-Karyorrhexis Index. NCI Thesaurus. Code

C118955.

An index used in neuroblastic tumors indicating the presence of less than 100 mitoses and karyorrhexis per 5,000 cells. 